\title{
Effects of Varieties and Intra Row Spacing on Yield of Maize (Zea mays L) Under Supplementary Irrigation in an Arid Region of Western Ethiopia
}

\author{
Tasisa Temesgen \\ School of Natural Resource Management and Environmental Sciences, Haramaya University, Dire Dawa, Ethiopia
}

Email address:

tasisatemesgen@gmail.com

\section{To cite this article:}

Tasisa Temesgen. Effects of Varieties and Intra Row Spacing on Yield of Maize (Zea mays L) Under Supplementary Irrigation in an Arid Region of Western Ethiopia. Advances in Applied Sciences. Vol. 4, No. 2, 2019, pp. 44-50. doi: 10.11648/j.aas.20190402.13

Received: March 16, 2019; Accepted: May 6, 2019; Published: May 31, 2019

\begin{abstract}
Determination of optimum plant population and the use of improved varieties in combination with appropriate agronomic practices are important components of maize production package for maximizing productivity. The study was conducted 2017- 2018 under supplementary irrigation at 9o 10' 00" N' latitude and 35o22' 00" E longitude, Western Ethiopia, to determining the effects of variety and intra-row spacing on yield of maize (Zea mays L.), the same application of irrigation water. The experiment was conducted in factorial arrangement of four intra-row spacing $(20,25,30$ and $35 \mathrm{~cm})$ with three maize varieties (BH546, Shone and BHQPY-545) in RCBD. The interaction of variety and intra-row spacing was highly significant $(\mathrm{P}<0.01)$ on yield components and yield of maize. The highest $(1.75)$ average number of ears per plant was recorded from varieties BH546 and BHQPY -545 at $35 \mathrm{~cm}$ intra-row spacing. The highest $(35 \mathrm{~cm})$ ear length was recorded from BH546 at $35 \mathrm{~cm}$ intra-row spacing. Generally, leaf area, stand count, ears per plant, ear length, and ear diameter showed a decreasing trend with decreasing intra-row spacing. Based on these results, it can be tentatively concluded that the variety BH546 could be used at plant density of 53,333 plants ha-1 and $(25 \mathrm{~cm})$ intra-row spacing is best to get the highest green cob yield of maize under supplemental irrigation during the off-season in the study area.
\end{abstract}

Keywords: Intra-row Spacing, Supplementary Irrigation, Plant Density and Crop Variety

\section{Introduction}

Maize (Zea mays L) is the most widely grown cereal crop in Ethiopia. It ranks third after wheat and rice in hectare and total production. It is predicted that by 2020 , it will surpass both wheat and rice to become the number one cereal in the world Maize demand is projected to increase by $50 \%$ worldwide' and by $93 \%$ in sub-Saharan Africa between 1995 and 2020 [1].

Supplementary irrigation method is some of the methods with high soil water conservation potential, especially during off rain season. Supplemental irrigation aims to overcome the effects of drought periods as soil moisture drops and halts crop growth and development.

Different variety of Maize is very sensitive to drought at different growth stages from germination to maturity [2]. In the development growth stages of maize drought affect cell division and cell proliferation [2], while in the reproductive stage drought affecting tassel, embryo endosperm development, ear, pollination, fertilization grail filling and resulting the loss of crop yield. While most of sub Saharan Africa maize production is based on rainfed systems [3], there is a need to find out alternative soil moisture conservation strategies to mitigate drought effects. In these regards mulching, tied ridges, terracing, bunding, supplementary irrigation method are some of the methods with high soil water conservation potential. Supplemental irrigation (SI) is a key strategy, although it is still underused, for unlocking rainfed yield potential and water productivity in rainfed areas having perennial water sources in the study area [3].

In Ethiopia, the national spacing recommendation for maize is $75 \mathrm{~cm} \times 30 \mathrm{~cm}(44,444$ plants/ha). This spacing has been used, without taking into account the numerous factors such as the existences of soil and climatic differences. In the study area, the production of maize under irrigation takes on a special significance; because there is high demand for green fresh consumption during off season as long as water is 
available for irrigation and production during the off season. For this reason, farmers produce maize under irrigation with varied plant spacing and as a result, plant population per hectare varies among farmers due to miss using proper spacing. Some of the farmers say that the national recommended spacing is too wide that it does not give higher yield. Moreover, they think as use of higher plant population may result in more yields that was visually observed.

Thus, effects of different spacing during off rain season on maize have to be investigated for practical purposes, as planting spacing is a major management variable used in matching crop requirements to the environmental offer of resources. This study was addressed this problem with the objective: assess the effects of variety and intra- row spacing on yield of maize under supplementary irrigation.

\section{Materials and Method}

\subsection{Description of the Study Area}

The study was conducted at Western Ethiopia; the experimental site is situated at $9^{\circ} 10^{\prime} 00^{\prime \prime} \mathrm{N}^{\prime}$ latitude and $35^{\circ} 22^{\prime} 00^{\prime \prime} \mathrm{E}$ longitude at 1538 meters above sea level. The experiment was conducted under supplementary irrigation during 2017/2018 cropping season. The rainy season starts in May and extends up to October, the annual (May-beginning of November) rain fall of $1460.9 \mathrm{~mm}$, and the mean maximum and minimum air temperature of $27^{\circ} \mathrm{C}$ and $14.94^{\circ} \mathrm{C}$ respectively.

\subsection{Description of Experimental Materials}

Three hybrid maize varieties, (BH546 and BHQPY-545 which were used for the study were used under supplementary irrigation as experimental material. The yield potentials of BH546 and BHQPY 545 on research center were 8.5-11.5 ton $\mathrm{ha}^{-1}$ and 8-9 ton $\mathrm{ha}^{-1}$ respectively, While on farmers field their yield potential were 6.5-7.5 ton $\mathrm{ha}^{-1}$ and 56 ton ha $^{-1}$ respectively [4]. The variety Shone yield potential was 7-11 ton ha ${ }^{-1}$ and 6.5-8.5 ton $\mathrm{ha}^{-1}$ on research center and farmer field respectively [5] (Table 1).

Table 1. Descriptions of Maize Varieties used for study under supplementary irrigation.

\begin{tabular}{llllll}
\hline Variety & Year of release & Altitude $(\mathbf{m})$ & Rain Fall $(\mathbf{m m})$ & Days to maturity & Seed rate/ha $\mathbf{k g}$ \\
\hline BH546 & 2013 & $1000-1700$ & $1000-1200$ & 150 & $25-30$ \\
Shone(30G19) & 2008 & $1000-1200$ & $800-1200$ & 165 & $25-30$ \\
BHQPY-545 & 2008 & $1000-1700$ & $1000-1200$ & 145 & $25-30$ \\
\hline
\end{tabular}

\subsection{Treatments and Experimental Design}

The treatment consists of factorial combination of 4 intrarow spacing $(20,25,30$ and $35 \mathrm{~cm})$ and three varieties of maize (BH546, Shone (30G90) and BHQPY-545. The recommended inter row spacing of $75 \mathrm{~cm}$ for maize was used uniformly. The experiments were laid out in randomized complete block design (RCBD) in $4 \times 3$ factorial arrangements with three replications and full supplementary irrigation. The space between plot and block was $0.5 \mathrm{~m}$ and 1 $\mathrm{m}$ respectively. The gross plot consists of 4 rows, each $3 \mathrm{~m}$ long. The net plots were the middle 2 rows; the 2 outer rows of each plot were used as border rows. Thus, the size of the gross and net plot was $9 \mathrm{~m}^{2}(3 \mathrm{~m} \mathrm{x} 3 \mathrm{~m})$ and $4.5 \mathrm{~m}^{2}(3 \times 1.5$ $\mathrm{m})$. Thus, the plant population corresponding to the $20 \mathrm{~cm} \mathrm{x}$ $75 \mathrm{~cm}, 25 \mathrm{~cm} \times 75 \mathrm{~cm}, 30 \mathrm{~cm} \times 75 \mathrm{~cm}$ and $35 \mathrm{~cm} \times 75 \mathrm{~cm}$ intrainter row spacing were 66,666, 53333, 44444 and 38095 plants per hectare.

\subsection{Irrigation Management}

For the $1^{\text {st }}$ month field was shallow irrigated at 7 interval days, while after a month till to tasseling and silking irrigation 10 to 12 days interval applied deeply by furrow system. And at critical time at tasseling and silking stage field was irrigated by 4 days interval to initiate flowering and silking. Most of the time irrigation has been done after noon to avoid loses of water from the field by evaporation.

\subsection{Data Collection and Measurement}

\subsubsection{Phenological and Growth Parameters of Maize}

Days to $50 \%$ anthesis, Days to $50 \%$ silking, Leaf area, Leaf area index (LAI); Plant height $(\mathrm{cm})$ and Plant height $(\mathrm{cm})$ were measured

\subsubsection{Yield and Yield Component}

Number of ears per plant, Ear height $(\mathrm{cm})$, Number of kernels per ear, hundred kernels weight $(\mathrm{g})$, Grain yield $\left(\mathrm{kg} \cdot \mathrm{ha}^{-1}\right)$ and Harvest index were collected at the time of data collection

\subsection{Statistical Data Analysis}

The measurement variables were analyzed using the statistical analysis system (SAS) as per the RCBD factorial model. Mean separation was conducted using LSD at 5\% level of significance.

\section{Results and Discussion}

\subsection{Phenological Parameters of Maize}

\subsubsection{Days to 50\% Anthesis}

The impact of SI goes beyond yield increase to substantially improving water productivity. The productivity of irrigation water and rainwater is improved when they are used conjunctively. Using irrigation water conjunctively with rain was found to produce more wheat per unit of water than if used alone in fully irrigated areas where rainfall is negligible. 
The other is the main effect of variety showed highly significant $(\mathrm{P}<0.01)$ effect while intra- row spacing and the interactions did not affect significantly days of $50 \%$ anthesis.

The longest days to $50 \%$ anthesis ( 82.00 days) was recorded from variety Shone; while the shortest (79.50) was recorded under variety BHQPY-545 (Table 2). It might be due to the genetic variation between the varieties on maturity period. This finding is in line with [6] who stated that there were difference in days to anthesis and days to silking among maize genotypes.

\subsubsection{Days to 50\% Silking}

The period of silking is a critical time for kernels formation after pollination. Any factor that affects silking and duration of silking can affect grain production directly. The main effect of variety showed highly significant $(\mathrm{P}<0.01)$ effect on $50 \%$ days to silking, while intra- row spacing and the interactions did not significantly affect days to $50 \%$ silking.

Varity Shone took the longest (86.58) days to reach 50\% silking stage, while variety BHQPY-545 took shortest (83.08) days. There was significant difference among all varieties (Table 2). The significant difference among the varieties might be due to the variation in the genetic characteristics of the varieties. This finding is in line with that who stated that there were difference in days to anthesis and days to silking among maize genotypes [6], while this finding disagree with that who reported that plant density affects the required interval for pollen shedding and silk emergence were takes long days as planting density of maize increased [7].

Table 1. Main effect of variety and intra-row spacing on days to anthesis and silking under supplementary irrigation.

\begin{tabular}{lll}
\hline Treatment & $\mathbf{5 0 \%}$ Days of anthesis & $\mathbf{5 0 \%}$ Days to silking \\
\hline Maize Variety & & \\
Shone (30G19) & $82.00^{\mathrm{a}}$ & $86.58^{\mathrm{a}}$ \\
BH 546 & $79.83^{\mathrm{b}}$ & $84.42^{\mathrm{b}}$ \\
BHQPY-545 & $79.50^{\mathrm{b}}$ & $83.08^{\mathrm{c}}$ \\
LSD(0.05) & 1.137 & 0.914 \\
Intra row spacing (cm) & & \\
20 (66,667 PP) & 79.89 & 84.11 \\
25 (53,333 PP) & 80.44 & 84.78 \\
30 (44,444 PP) & 80.33 & 84.67 \\
$35(38,093 \mathrm{PP})$ & 81.11 & 85.22 \\
LSD $(0.05)$ & $\mathrm{NS}$ & $\mathrm{NS}$ \\
CV $(\%)$ & 1.4 & 1.3 \\
\hline
\end{tabular}

LSD $(5 \%)=$ Least significance difference at $0.05 \%$ level $\mathrm{CV}=$ Coefficient of variation; $\mathrm{NS}=$ non-significant, $\mathrm{PP}=$ plants $\mathrm{ha}^{-1}$. Means in the same column with in a parameter followed by the same letter(s) are not significantly different at $5 \%$ level of significance.

\subsection{Growth Parameters of Maize}

\subsubsection{Leaf Area}

The analysis of variance showed highly significant $(p<0.01)$ difference in leaf area due to main effect of intrarow spacing. There was no significance difference due to variety and interaction. The highest leaf area $\left(6291 \mathrm{~cm}^{2}\right)$ was recorded from $35 \mathrm{~cm}$ intra-row spacing $\left(38,093\right.$ plants $\left.\mathrm{ha}^{-1}\right)$ which was statistically at par with at $30 \mathrm{~cm}$ intra-row spacing, while the lowest $\left(5867 \mathrm{~cm}^{2}\right)$ was recorded from $20 \mathrm{~cm}$ intra-row spacing $\left(66,667\right.$ plants $\left.\mathrm{ha}^{-1}\right)$ (Table 3$)$. This might be due to that reduction of leaf area as a result of increasing plant density that led to the accelerated leaf senescence, increased shading of leaves, and reduced net assimilation of individual plants. This is in agreement with [6] who reported that the leaf area per plant tended to decline with increasing plant density in maize. Similarly, [6] reported that lower plant population got more nutrients and water compared to higher population, thus contributed increased leaf area unlike high plant population density that reduced that reduced low leaf area of maize decreased.

\subsubsection{Leaf Area Index}

Leaf area index (LAI) showed highly significant $(\mathrm{P}<0.01)$ effect as affected by the main effect of intra-row spacing; but there was significant effect of variety and interaction.

The highest LAI (4) was recorded under $20 \mathrm{~cm}$ intra-row spacing with plant density of 66,667 plants $\mathrm{ha}^{-1}$ and the lowest (12) was observed under $35 \mathrm{~cm}$ intra-row spacing with 38,093 plants $\mathrm{ha}^{-1}$. Leaf area index significantly decreased as plant density increased from 38,093 plants ha ${ }^{-1}(35 \mathrm{~cm}$ intra-

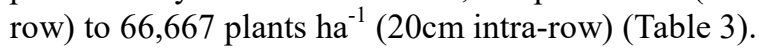

In the current study, increase of LAI at narrowest row spacing $\left(66,667\right.$ plants $\left.\mathrm{ha}^{-1}\right)$ and decrease with increasing intra-row indicates that LAI decrease as plant density increase. This study agrees with that of (6) who reported that LAI is influenced by genotype, plant population, climatic condition and soil fertility.

However; this study agree with that of [7] who reported that LAI of maize was significantly affected and increased in linear fashion with increase plant population. Other workers found results which disagree this finding. [6] reported maximum LAI from the lowest plant density and minimum LAI from the highest plant density. In this case, increase in number of plants per unit area beyond optimum level could probably reduce the amount of light availability to the individual plant, especially, to lower leaves due to shading. Generally, consistent increments in LAI were observed with increased plant population density. This dramatic increase in LAI with reduced intra row spacing or with increase in the plant population density might be due to occupation of more unit area by green canopy of the plants.

\subsubsection{Plant Heights}

The analysis of variance showed statistically significant $(\mathrm{P}<0.05)$ different in plant height due to main effects of the variety; but there is no significance difference due to intrarow spacing and interaction effects. This finding agrees with report of [8] that had been significant plant height difference among maize cultivar.

Variety Shone was the tallest $(263.3 \mathrm{~cm})$, while variety BHQPY-545 was the shortest $(235.5 \mathrm{~cm})$ (Table 3). This variation showed the existence of genetic difference among the varieties. In conformity with this result, [9] reported considerable varietal variation among plant height of maize cultivars. Narrow plant spacing is longer plant height 85.22 
from $20 \mathrm{~cm}$ intera-row spacing; while the shortest $(84.11 \mathrm{~cm})$ plant height from wide $35 \mathrm{~cm}$ intera-row spacing this is may

be due to nutrients competition

Table 2. Main effect of leaf area, LAI and Plant height on space and variety of green cob maize.

\begin{tabular}{llll}
\hline Treatment & LA $\left(\mathbf{c m}^{2}\right)$ & LAI & PH $(\mathbf{c m})$ \\
\hline Maize Varieties & & & $255.0^{\mathrm{a}}$ \\
BH546 & 6171 & 3.168 & $235.5^{\mathrm{b}}$ \\
BNQPY-545 & 6090 & 3.143 & $263.3^{\mathrm{a}}$ \\
Shone(30G19) & 6085 & 3.113 & 14.643 \\
LSD (0.05) & $\mathrm{NS}$ & $\mathrm{NS}$ & 257.8 \\
Intra row spacing & & & 253.3 \\
20 (66,667PP) & $5867^{\mathrm{b}}$ & $3.975^{\mathrm{a}}$ & 254.0 \\
25 (53,333PP) & $6018^{\mathrm{b}}$ & $3.263^{\mathrm{b}}$ & 240.0 \\
$30(44,444 \mathrm{PP})$ & $6285^{\mathrm{a}}$ & $2.852^{\mathrm{c}}$ & $\mathrm{N} . \mathrm{S}$ \\
$35(38,093 \mathrm{PP})$ & $6291^{\mathrm{a}}$ & $2.476^{\mathrm{d}}$ & 6.9 \\
LSD $(0.05)$ & 143.8 & 0.10 & 3.7 \\
CV (\%) & 2.8 & & \\
\hline
\end{tabular}

$\mathrm{LA}=$ leaf area, $\mathrm{LAI}=$ leaf area index, $\mathrm{PH}=$ plant height. $\mathrm{LSD}(5 \%)=$ Least significance difference at $5 \%$ level, $\mathrm{CV}(\%)=$ Coficiaont of variation in percent; $\mathrm{NS}=$ non-significant. $\mathrm{PP}=$ the number in parentheses indicate plant ha ${ }^{-1}$, Means column with in a parameter followed by the same letter(s) are not significantly different at $5 \%$ level of significance.

\subsection{Yield Component and Yield}

\subsubsection{Stand Count (\%)}

The maize percent stand count was highly significantly $(\mathrm{P}<0.01)$ affected by the main effect of variety and intra-row spacing but the interaction effect was non significant. The highest $(96.60 \%)$ stand count was recorded from variety BH546 and the lowest (91.56\%) from variety BHQPY -545 (Table 4). This can be attributed to genetic difference of the varieties. Regarding the intra-row spacing the highest (97.92\%) stand count was recorded from $35 \mathrm{~cm}$ intra-row spacing, while the lowest $(89.63 \%)$ was recorded from $20 \mathrm{~cm}$ intra-row spacing (Table 4).

Stand count percent increase at wider intra-row spacing and decrease at narrow intra-row spacing. In general, plant stand percent decreased as plant population increased and this might be due to crowding effect. The other reason is that at lower population comparatively availability of more space might have resulted in less competition for resources (nutrients, moisture and light) where as at high density competition resulted in weaker plants and mortalities by the time the crop approached maturity. This result agrees with; [12] who reported higher plant stand count percent due to wider spacing combination of $75 \mathrm{~cm} \times 30 \mathrm{~cm}$ than narrow spacing of $55 \mathrm{~cm} \times 20 \mathrm{~cm}$. Similarly, [13] report that who wider inter and intra-row spacing of $75 \mathrm{~cm} \times 26.6 \mathrm{~cm}$ had greater plant stand count percent of maize compared to the initial count than that of narrow inter and intra-spacing of $50 \mathrm{~cm} \times 17.7 \mathrm{~cm}$.

\subsubsection{Ear Diameter}

The main effect of intra-row spacing showed highly significant $(\mathrm{P}<0.01)$ effect on maize diameter while that of variety was significant $(\mathrm{P}<0.05)$ effect on ear diameter. However, the interaction effect was not significant. The highest ear diameter $(4.19 \mathrm{~cm})$ was record from variety BH546, while the lowest (3.99) was produced by variety BHQPY-545. The ear diameter of variety BHQPY-545 and shone were not significantly different (Table 4). This might be due to genetic variation among the varieties. The highest $(4.29 \mathrm{~cm})$ and the lowest $(3.82 \mathrm{~cm})$ ear diameter were recorded at intra-row spacing of $35 \mathrm{~cm}$ and $20 \mathrm{~cm}$ respectively (Table 4).

There was statistically significant difference among 20, 25, and $35 \mathrm{~cm}$ and no significance difference between 30 and $25 \mathrm{~cm}$ intra-row spacing. Ear diameter increase as intra-row increased. This might be because of comparatively less computation for resources like moisture, nutrient, and light in low in this plant population density.

Table 3. Main effect of intra-row spacing and varieties on stand count (\%) and ear diameter of maize under supplementary irrigation.

\begin{tabular}{lll}
\hline Treatment & Stand count (\%) & Ear diameter $(\mathbf{c m})$ \\
\hline Maize Variety & & \\
BH 546 & $96.60^{\mathrm{a}}$ & $4.19^{\mathrm{a}}$ \\
BHQPY-545 & $91.56^{\mathrm{b}}$ & $3.99^{\mathrm{b}}$ \\
Shone (30G19) & $93.20^{\mathrm{b}}$ & $4.04^{\mathrm{b}}$ \\
LSD (0.05) & 2.16 & 0.1378 \\
Intra row-row spacing $(\mathrm{cm})$ & & \\
20 (66,667pp) & $89.63^{\mathrm{c}}$ & $3.82^{\mathrm{c}}$ \\
25 (53,333pp) & $92.59^{\mathrm{b}}$ & $4.02^{\mathrm{b}}$ \\
$30(44,444 p p)$ & $95.00^{\mathrm{b}}$ & $4.16^{\mathrm{ab}}$ \\
$35(38,093 \mathrm{pp})$ & $97.92^{\mathrm{a}}$ & $4.29^{\mathrm{a}}$ \\
LSD P $<0.05)$ & 2.50 & 0.1591 \\
C.V $(\%)$ & 2.7 & 4.0 \\
\hline
\end{tabular}

LSD $(5 \%)=$ Least significance difference at $5 \%$ level CV $(\%)=$ Coefficient of variation; $\mathrm{NS}=$ non-significant at $5 \%$ level and $\mathrm{SC}=$ stand count in $\%$, pp= the number in parentheses indicate plant $\mathrm{ha}^{-1}$, Means in the same column with in a parameter followed by the same letter(s) are not significantly different at $5 \%$ level of significance.

\subsubsection{Number of Ears Per Plant}

The analysis of variance showed highly significant $(\mathrm{P}<0.01)$ effect of intra-row spacing, variety and the interaction on number of ears per plant. The highest (1.75) number of ear plant ${ }^{-1}$ was scoured from the interaction of the 
variety BH546 and BHQPY-545 with $35 \mathrm{~cm}$ intra- row spacing produced.

This showed that variety BH546 and BHQPY-545 performed better at $35 \mathrm{~cm}$ intra-row spacing in bearing ears per plant than at other spacing and variety Shone. The lowest (1.00) ear per plant was recorded from the variety Shone and BH 546 with $20 \mathrm{~cm}$ intra- row spacing. In general number of ear per plant increased in all varieties as intra-row increased (Table 5).

This study agrees with [14] who report that as plant density in unit area increased the numbers of ears per plants become decrease due to competition among the plants. Also in line with this result [13] reported significantly higher number of cobs plant-1 at lower plant density compared to higher plant density. Variety (Shone) the lowest ears per plant than the other two varieties at all intra row spacing, except at $20 \mathrm{~cm}$ produced. In this currently study generally number of ear per plant increase in all varieties as intera-row spacing increased.

Table 4. Interaction effect of varieties and intera-row spacing on number of ears per plant.

\begin{tabular}{lllll}
\hline \multicolumn{5}{l}{ Intra-row spacing $(\mathbf{c m})$} \\
\hline Maize Varieties & $\mathbf{2 0}$ & $\mathbf{2 5}$ & $\mathbf{3 0}$ & $\mathbf{3 5}$ \\
\hline BH 546 & $1.01^{\mathrm{f}}$ & $1.53^{\mathrm{bc}}$ & $1.55^{\mathrm{b}}$ & $1.75^{\mathrm{a}}$ \\
BHQPY-545 & $1.03^{\mathrm{f}}$ & $1.43^{\mathrm{cd}}$ & $1.63^{\mathrm{b}}$ & $1.75^{\mathrm{a}}$ \\
Shone(30G19) & $1.00^{\mathrm{f}}$ & $1.23^{\mathrm{e}}$ & $1.37^{\mathrm{d}}$ & $1.39^{\mathrm{d}}$ \\
LSD (0.05) & 0.1156 & & & \\
CV (\%) & 4.9 & & & \\
\hline
\end{tabular}

$\mathrm{LSD}=$ least significant difference, $\mathrm{NS}=$ non significance $\mathrm{CV}=$ coefficient of variation in percent. Means column with in a parameter followed by the same letter(s) are not significantly different at $5 \%$ level of significance.

\subsubsection{Ear Length}

The analysis of variance showed that ear length was highly significantly $(\mathrm{P}<0.01)$ affected by the main effect of intrarow spacing, variety and their interaction.

The significantly longest ear $(35.00 \mathrm{~cm})$ was recorded from BH546 treated under $35 \mathrm{~cm}$ intra-rows spacing at plant density 38,095 plants $\mathrm{ha}^{-1}$. The shortest ear length $(23 \mathrm{~cm})$ was obtained from Shone grown at intra-row spacing $20 \mathrm{~cm}$ $\left(66,667\right.$ plants $\left.\mathrm{ha}^{-1}\right)$. In general ear length decreased with decreased intra-row spacing (increased plant density) (Table 6). The longer ear at lower plant population (increased intrarow spacing) might be due to the fact that at lower population level there are available space and less competition for resources in low plant population density.

Regarding the longest ear $(35 \mathrm{~cm})$ of maize was observed from variety BH546 treated fewer than $35 \mathrm{~cm}$ intra-rows spacing; while the variety BHQPY -545 produced shortest ear length $(31.67 \mathrm{~cm})$ at the same intra-row spacing might be due to genetic variation among these varieties. This result is in line with the finding [15], who reported significant differences among the varieties of maize for ear length. Similarly [16] where they reported significant differences among the varieties of maize in ear length and ear diameter.

A study [11] also observed decreased maize ear length under increased population densities and attributed that the plant population above and below critical density has a negative effect on yield per plant due to the effects of inter plant competition for light, water, nutrient and other potential yield-limiting environmental factors. Reduction of ear length and diameter with narrower row spacing is attributed to limitation of assimilates as a result of low photosynthetic processes of leaves at narrow row spacing due to less availability of growth influencing factors and genetic variation among the varieties, which resulted in high or low ear length and diameter.

Table 5. Interaction of varieties and intera-row spacing on ear length at harvest of green cob maize.

\begin{tabular}{lllll}
\hline \multicolumn{5}{c}{ Intra-row spacing } \\
\hline Maize Variety & $\mathbf{2 0 c m}$ & $\mathbf{2 5 c m}$ & $\mathbf{3 0 c m}$ & $\mathbf{3 5 c m}$ \\
\hline BH546 & $27.33^{\text {gh }}$ & $29.75^{\mathrm{e}}$ & $31.00^{\text {cd }}$ & $35.00^{\mathrm{a}}$ \\
BHQPY-545 & $25.28^{\mathrm{i}}$ & $28.17^{\mathrm{fg}}$ & $28.47^{\mathrm{f}}$ & $31.67^{\mathrm{bc}}$ \\
Shone(30G19) & $23.00^{\mathrm{j}}$ & $26.33^{\text {gh }}$ & $30.08^{\mathrm{cd}}$ & $32.33^{\mathrm{b}}$ \\
LSD (0.05) & 1.039 & & & \\
CV (\%) & 2.1 & & & \\
\hline
\end{tabular}

LSD =least significant difference, CV (\%) =coefficient of variation in present, $\mathrm{pp}=$ the number in the parentheses indicate plant ha ${ }^{-1}$, Means column with in a parameter followed by the same letter(s) are not significantly different at $5 \%$ level of significance.

\subsubsection{Number of Ears Per Hectare}

The main effect of intra-row spacing showed highly significant $(\mathrm{P}<0.01)$ effect on ear per hectare and variety showed significant $(\mathrm{p}<0.05)$ effect. But, the interaction effect was non-significant effect.

The highest $(57,962)$ number of ears per hectare was obtained from variety BH546, while the lowest $\left(52,037 \mathrm{ha}^{-1}\right)$ was from variety Shone. Variety BHQPY 545 was at par with BH546 and Shone varieties. Variety BH546 gave more ear $\mathrm{ha}^{-1}$ than the other two varieties, indicating that this variety is preferable than other in terms of cob number (Table 7). The highest number of ear $\left(62,222 \mathrm{ha}^{-1}\right)$ was recorded from $25 \mathrm{~cm}$ intra-row spacing at plant population $(53,333$ ha-1) which was statistically at par with $\left(57,530 \mathrm{ha}^{-1}\right)$ from $20 \mathrm{~cm}$ intrarow spacing $\left(66,667\right.$ plants $\left.\mathrm{ha}^{-1}\right)$. There was no significant difference between $20 \mathrm{~cm}$ and $25 \mathrm{~cm}$ intra row spacing, indicating that one of the two could be used for green cob production; while $25 \mathrm{~cm}$ intera-row spacing is the best one. The lowest $(47,654)$ number of ear per hectare was recorded from $35 \mathrm{~cm}$ intra-row spacing.

This finding agrees with [11] who reported that grain yield increased with increasing plant density linearly until production factors are not limiting. Also it is in line with [17] who report that intra-row spacing $25 \mathrm{~cm}$ resulted in the highest (23.11) cob per plot $30 \mathrm{~cm}$ followed (21.56) ; while $20 \mathrm{~cm}$ resulted the least $(17.78)$ cob per plot. In this current study the reason $25 \mathrm{~cm}$ intera-row spacing record high cob yield ha ${ }^{-1}$ was the plant population is greater than that of 30 and $35 \mathrm{~cm}$ intera-row spacing; while $20 \mathrm{~cm}$ intera-row spacing may affected by limitation factor than the other. 
Table 6. Maine effect of varieties and intera-row space ears per hectare on green cob maize.

\begin{tabular}{ll}
\hline Treatment & Ear/ha \\
\hline Maize Variety & \\
BH 546 & $57,962^{\mathrm{a}}$ \\
BHQPY-545 & $55,000^{\mathrm{ab}}$ \\
Shone (30G19) & $52,037^{\mathrm{b}}$ \\
LSD $(0.05)$ & 4267.2 \\
Intra-row spacing (cm) & \\
20 (66,667PP) & $57,530^{\mathrm{a}}$ \\
$25(53,333 \mathrm{PP})$ & $62,222^{\mathrm{a}}$ \\
$30(44,444 \mathrm{PP})$ & $52,592^{\mathrm{b}}$ \\
$35(38,093 \mathrm{PP})$ & $47,654^{\mathrm{c}}$ \\
LSD $(0.05)$ & 4927.3 \\
CV $(\%)$ & 9.2 \\
\hline
\end{tabular}

LSD = least significant difference, $\mathrm{CV}(\%)=$ coefficient of variation in percent, $\mathrm{PP}=$ the number in the parentheses indicate plants ha-1, Means column with in a parameter followed by the same letter(s) are not significantly different at $5 \%$ level of significance.

\section{Summary and Conclusion}

Among agronomic practices, variety and plant spacing require special attention. Therefore, the present experiment was conducted in 2017/18 irrigation cropping season at the study area, with the objectives of assessing the effects of maize variety and intra-row spacing on growth, yield and yield components, and on green cob yield of maize. The treatment consisted of factorial combination of 4 intra-row spacing (20, 25,30 and $35 \mathrm{~cm}$ ) and three varieties of maize (BH546, Shone, and BHQPY-545). The recommended inter row spacing of $75 \mathrm{~cm}$ for maize was used uniformly. The experiments were laid out in randomized complete block design (RCBD) in $4 \times 3$ factorial arrangements with three replications.

The main effect of variety was highly significant $(\mathrm{P}<0.01)$ on days to $50 \%$ anthesis, days of $50 \%$ silking, plant height, ear diameter, and ears per hector; whereas intra-spacing and interaction were not significant. The variety Shone took maximum (82) days to reach $50 \%$ anthesis; while the variety BHQPY-545 took minimum (79.50) days to reach 50\% anthesis. Variety shone took the longest (86.56) days to reach $50 \%$ of silking; while variety BHQPY -545 was the earliest (83.08) to reach days to $50 \%$ silking stage.

Intra-row spacing had highly significant $(\mathrm{P}<0.01)$ effect on plant leaf area and leaf area index. The highest leaf area $\left(6291 \mathrm{~cm}^{2}\right)$ was recorded from $35 \mathrm{~cm}$ intra-raw spacing, which was statistically at par with $30 \mathrm{~cm}$ intra-row spacing $\left(6285 \mathrm{~cm}^{2}\right)$. Leaf area index showed an increasing trend with decreasing intra-row spacing. The highest (3.975) leaf area index recorded was from $20 \mathrm{~cm}$ intra-row spacing, while the minimum (2.476) leaf area index recorded was from $35 \mathrm{~cm}$ intra-row spacing. Variety Shone (30G19) had the tallest plant height $(263.3 \mathrm{~cm})$, while the variety BHQPY -545 was shortest $(235.5 \mathrm{~cm})$.

BH546 gave the highest ear diameter $(4.19 \mathrm{~cm})$, while variety BHQPY-545 gave the narrowest ear diameter $(3.99 \mathrm{~cm})$. Regarding the main effect of intra-row spacing, the largest diameter $(4.29 \mathrm{~cm})$ was obtained from $35 \mathrm{~cm}$ intra-row with plant population density of 38,095 plants $\mathrm{ha}^{-1}$, while the smallest $(3.82 \mathrm{~cm})$ ear diameter was recorded from $20 \mathrm{~cm}$ intra-row spacing. The highest number of ears per hectare $(57,962)$ was obtained from variety BH546, while the lowest number of ears $(52,037) \mathrm{ha}^{-1}$ was recorded from variety Shone. Intra-row spacing also has significant different ear ha${ }^{1}$; the highest ears $\mathrm{ha}^{-1}$ recorded from $20 \mathrm{~cm}$ and $25 \mathrm{~cm}$ at par with $(57,530)$ and $(62,222)$; while the lowest ears $\mathrm{ha}^{-1}$ was recorded at $35 \mathrm{~cm}$ intra-row spacing.

Variety with intra-row spacing had highly significant effect on the number of ears per plant and ear length. The highest (1.75) number of ear plant ${ }^{-1}$ was obtained from BH546 at $35 \mathrm{~cm}$ intra- row spacing, whereas, the lowest (1.00) number of ears per plants was form Shone at $20 \mathrm{~cm}$ intra-row spacing. This result showed that the varieties BH546 and BHQPY-545 at $35 \mathrm{~cm}$ intra-row spacing were better in bearing ears per plant, having an average of 1.75 ears per plant.

The highest ear length $(35 \mathrm{~cm})$ was recorded from BH546 with intra-row spacing of $35 \mathrm{~cm}$, while the shortest ear lengths $(23 \mathrm{~cm})$ was obtained from Shone (30G19) at intrarow spacing $20 \mathrm{~cm}$. Generally, long ears were observed at lower plant populations, which might be due to less competition, thus more available space and resources for individual plants to produce long ears at low plant density.

Finally, the result of present study showed that variety and intra-row spacing had significant influences on most of the phonological parameters, yield and yield components of maize. The result also indicated that variety BH546 was the most suitable of the three maize varieties tested, and $25 \mathrm{~cm}$ intra-row spacing was better to achieve optimum yield. However, this is a one season experiment at one location, thus the experiment has to be repeated over locations and seasons to reach at a better reliable conclusion.

\section{References}

[1] FAO, 2015, The State of Food and Agriculture Social protection and agriculture: breaking the cycle of rural poverty.

[2] Muhammad, A., Muhammad, A., M., and Cengiz, R. 2015. Drought stress in maize (Zea mays L.) effects, resistance mechanisms, global achievements and biological strategies for improvement (pp. 1-79).

[3] Beyenesh Zemichael and Nigussie Dechassa. 2017. Performance of bread wheat (TriticumaestivumL.) in response tosupplemental irrigation and rate of nitrogen application inEnderta, Tigray, Northern Ethiopia. Int. J. of Life Sciences, 2017, Vol. 5 (3): 345-361.

[4] Mupangwa, M. and Dagne Wegary. 2018. Closing the gap between the potential yield and obtained results of improved maize varieties: Case for Ethiopia. African Seed Association (AFSTA) Congress, at Cairo, Egypt (CIMMYT).

[5] Malaku Adimasu. 2014. Hybrid maize seed production manual. Ethiopia Seed Association. Addis Ababa, Ethiopia.

[6] Kahiu Ngugi, Jerono Cheserek, Cecilia Muchira and George Chemining'wa. 2013. Anthesis to Silking Interval Usefulness in Developing Drought Tolerant Maize. Dept of Plant Sciences and Crop Protection, Faculty of Agriculture, College of Agriculture and Veterinary Sciences, University of Nairobi, Nairobi, Kenya. 
[7] Tokatlis, I. S. \& Koutroubas, S. D. 2004. A review of maize hybrids dependence on high plant populations and its implications for crop yield stability. Field Crops Research, 49:119-126

[8] Raouf, S. S., Sedghi, M. and Gholipouri, A., 2009. Effect of Population Density on Yield and Yield attribute of maize hybrids. Research journal of Biology sciences 4 (4): 375-379.

[9] Abuzar, M. R., Sodazai, G. U., Bolach, M. S., Bolach, A. A, Shah, I. H, avaid, T. J. and Hussa, N. 2011. Effect of Plant Population Densities on Yield of Maize. The journal of Animal and Plant Sciences, 21(4):692-695.

[10] Adeniyan, O. N. and Ojeniyi, S. O. 2005. Effect of poultry manure, NPK 15-15-15 fertilizer and combination on of their reduced levels on maize growth and soil chemical properties. Nigerian J. Soil Sci. 15: 34-41.

[11] Eskandarnejada, S., Khorasani, S., Bakhtiaric, A. Heidarian, R. 2013. Effect of row spacing and plant density on yield and yield components of sweet corn (Zea mays L.). Journal of Crop Science, 13 (1): 81-8.

[12] Sangoi, L., M. Ender, A. Guidolin, M. L. de Almeida and P. C.
Heberle, 2001. Influence of row spacing reduction on maize grain yield and yield components. Agronomy Journal, 36 (6) 861-869.

[13] Zamir, M. S. I., Ahmad, A. H., Javeed, H. M. R. and Latif, T. 2011. Growth and yield behavior of two maize hybrids (zea mays L.) towards different plant spacing. Cercetări Agronomiceîn Moldova Vol. XLIV, No. 2 (146).

[14] Kunoskan, O. 2000. Effect of plant density on yield and yield related characters on of some maize hybrids grown in hatey condition as second crop. M. SC. Thesis, Science Institute. M. K. U. 8(3): 71-75.

[15] Lakew Getaneh, Ketema Belete and Tamado Tana .2016 Growth and Productivity of Maize (Zea mays L.) as Influenced by Inter and Intra-Row Spacing in Kombolcha, Eastern Ethiopia. MSc, Thesis, Haramaya University, Haramaya, Ethiopia.

[16] Sabo, M. U, Wailare, M. A., Aliyu, M. J. and Sanusi, M. H. 2016. Effect of variety and spacing on growth and yield of maize (Zea mays L.) in Bauchi State, Nigeria. Int. Plant and Soil Sci. 2016; 9 (6):1-6. 